\title{
Vamos constituir nosso próprio
}

\section{POder! Cidadas e cidadãos do Povo da Terra (París 2015)}

Nós, cidadãs e cidadãos do Povo da Terra, de todos os países, culturas e tradições, reunidos em Paris neste momento histórico, testemunhas $d$ o desequilíbrio climático e da degradação dos recursos naturais essenciais para a vida na Terra e da crescente desigualdade entre os seres humanos, estamos determinados a preservar a capacidade de bem viver dasgerações presentes e futuras. Empoderados de nossos conhecimentos e culturas e tendo mobilizado nossa capacidade de agir em múltiplas iniciativas em todo o mundo visando a Grande Transição, vemos com preocupação a inadequação e a incapacidade do processo de negociação das Nações Unidas desde 1992 até 2015, de fazer um acordo ambicioso, corajoso e convincente para evitar maiores consequências de um desequilíbrio climático anunciado há muito tempo por cientistas e cujos efeitos desastrosos são agora evidentes.

É tempo de reconhecer que o sistema de representação da cidadania através dos Estados-Nação e de organizações multilaterais constituídas exclusivamente por esses, assim como o poder de uma oligarquia financeira e corporativa poderosa, sem qualquer legitimidade, são incapazes de preservar e gerir os bens comuns sem fronteiras da Terra, como o ar, a água, o solo, as florestas, dos quais depende fundamentalmente a vida humana e dos demais seres vivos. Precisamos inventar uma nova esfera de ação política que reconheça os povos em sua diversidade, mas também o Povo da Terra em sua unidade.

É urgente construir uma ação pública global a médio e longo prazo, capaz de levar em conta os interesses das gerações futuras. Precisamos de ações e decisões urgentes em escala global, que tenham um horizonte de tempo de no mínimo duas gerações, e até de sete, como sabiamente o fazem os povos indígenas da América do Norte.

É hora de dar mais um passo na capacidade de nossa família humana de garantir seu destino comum, evitando que ela ameace a si mesma, destruindo a Mãe 
Natureza que nutre a vida. Este passo é um processo constituinte, que, baseado na Declaração Universal dos Direitos Humanos, a complete com o reconhecimento pleno dos direitos e responsabilidades de cada ser humano para com os outros e com a Natureza, não só como cidadãs e cidadãos de nações e povos diferentes, mas também como cidadãs e cidadãos do Povo da Terra, cujo destino está intimamente relacionado com o do nosso belo e frágil planeta.

Estes direitos de cidadania planetária não podem continuar a serem reféns das organizações econômicas e políticas incapazes de resistirem ao poder do sistema oligárquico dominante que retarda as medidas urgentes que precisam ser tomadas para evitar maiores catástrofes sociais e ecológicas.

Propomos, então, a construção de um poder cidadão que assuma de forma complementar ao dos Estados, a responsabilidade pelo futuro da humanidade no planeta. Estamos empenhados em construir juntos esse poder com aquelas e aqueles que, livres das pressões de lobbies oligárquicos, entendem a urgência da ação e da construção de sua permanência no médio e longo prazo.

Propomo-nos a buscar todas as formas de organização e expressão do poder cidadão, baseando-se em todas as reuniões internacionais que virão.
Estaremos juntos por exemplo no Fórum Social Mundial Temático em Porto Alegre, em janeiro de 2016 e no Fórum Social Mundial em Montreal, em agosto de 2016, para se concentrar no que une os povos em defesa da vida e da própria humanidade, e ao mesmo tempo construir pontes para um reconhecimento oficial do poder cidadão pelas nações, pela ONU e suas agências, a fim de evitar a influência dos lobbies contrários à aventura humana Terra.

Portanto, nos comprometemos neste juramento solene:

Dedicar nossas capacidades, nossa cria tividade, nossa experiência intelectual, emocional, artística, material e imaterial, à aceleração imediata da Grande Transição para a energia renovável e limpa, para o abandono de combustíveis fósseis e de padrões de produção e consumo destrutivos para os seres humanos e o planeta, e a aplicação em todos os lugares e em todas as escalas-nossas famílias, nossas aldeias e nossas cidades, nossas regiões e nações- de uma nova economia igualitária, respeitosa da vida, da saúde, do bem-estar humano, bem como da biodiversidade e do equilíbrio de todos ecossistemas terrestres e aquáticos dos quais depende a sobrevivência da humanidade.

Fazemos este juramento, deixando $\mathrm{Pa}$ ris, de não nos separarmos uns dos ou- 
tros, nem no coração nem na mente; de manter nossas conexões através de todos os meios de meios de comunicação e de mídia cidadã; dese reunir sempre que as circunstâncias o exigirem; de exercer pressão sobre todas as instâncias de poder, seja governamental ou empresarial, corporativo e financeiro, local, nacional e global, para que assumam suas responsabilidades; de cooperar constantemente entre redes cidadãs para a implementação dos objetivos vitais e urgentes mencionadas acima; e, assim, fortalecer os nossos laços de amizade, irmandade, solidariedade e assistência mútua, a fim de expandir a rede global de cidadãs e cidadãos da Terra empenhados de corpo e alma nesta missão, atores da emergência de uma sociedade cívica mundial, portadores de um novo Contrato Social e Ecológico Planetário, garantidores desse juramento e desse compromisso em nosso nome e pela proteção das gerações vindouras.

Cidadãs e cidadãos do Povo da Terra, em Paris e em todo o mundo, confirmarão por sua assinatura esta inabalável resolução.

Paris, 12 de dezembro de 2015 